\title{
EVALUATION OF GERMINATION, EMERGENCE AND PHYSIOLOGICAL PROPERTIES OF SUGAR BEET CULTIVARS UNDER SALINITY
}

\author{
Engin Gökhan KULAN ${ }^{1 *}$, Alper ARPACIOĞLU ${ }^{1}$, Nurgül ERGİN ${ }^{2}$, Mehmet Demir KAYA $^{1}$ \\ ${ }^{1}$ Department of Field Crops, Faculty of Agriculture, Eskişehir Osmangazi University, Eskişehir, TURKEY \\ ${ }^{2}$ Department of Field Crops, Faculty of Agriculture and Natural Sciences, Bilecik Şeyh Edebali University, Bilecik, \\ TURKEY
}

Cite this article as

Kulan E.G., Arpacioğlu A., Ergin N. \& Kaya M.D. 2021. Evaluation of germination, emergence and physiological properties of sugar beet cultivars under salinity. Trakya Univ J Nat Sci, 22(2): 255-262, DOI: 10.23902/trkjnat.947001

Edited by:

Panagiotis Madesis

*Corresponding Author:

Engin Gökhan Kulan

egkulan@ogu.edu.tr

\section{ORCID iDs of the authors:}

EGK. orcid.org/0000-0002-7147-6896

AA. orcid.org/0000-0002-1176-2866

NE. orcid.org/0000-0003-3105-7504

MDK. orcid.org/0000-0002-4681-2464

\section{Key words:}

Beta vulgaris $L$

$\mathrm{NaCl}$

Relative water content

Chlorophyll content

Electrolyte leakage

\begin{abstract}
This study aimed to determine a useful selection criterion for salt tolerance during the early development stage of sugar beet. Four sugar beet cultivars (Orthega, Valentina, FD Shoot, and Mohican) were exposed to $\mathrm{NaCl}$ stresses (Control, 5, 10, and $15 \mathrm{dS} \mathrm{m}^{-1}$ ), and morphological and physiological characteristics were investigated. Germination percentage, mean germination time (MGT), seedling length, and seedling fresh weight (SFW) in germination test; emergence percentage, mean emergence time (MET), root length, shoot length, plant fresh weight, relative chlorophyll content (Chl), relative water content (RWC) and electrolyte leakage of the plants grown in pod experiment were measured. The results showed that the maximum germination at control was recorded in FD Shoot, but it gave the lowest germination at $15 \mathrm{dS} \mathrm{m} \mathrm{m}^{-1}$. In the pod experiment, the highest emergence rate was detected in Orthega and Mohican at all levels of $\mathrm{NaCl}$. Increased salinity delayed MET and led to reduction in shoot length, root length, and RWC of sugar beet cultivars. Relative Chl content and electrolyte leakage enhanced from 32.7 SPAD and $21.6 \%$ in control to 38.5 SPAD and $35.6 \%$ in $10 \mathrm{dS} \mathrm{m} \mathrm{m}^{-1}$, respectively. In general, there were significant differences among sugar beet cultivars, and they could keep the salinity up to $5 \mathrm{dS} \mathrm{m}^{-1}$ in terms of the investigated traits. It was concluded that relative $\mathrm{Chl}$ content and electrolyte leakage should be used a promising clue for selection of tolerant or sensitive sugar beet cultivars for salinity.
\end{abstract}

Özet: Bu çalışmada, erken gelişim döneminde şeker pancarının tuza toleransı için faydalı bir seçim kriteri belirlemek amaçlanmıştır. $\mathrm{NaCl}$ stresine (Kontrol, 5, 10 ve $15 \mathrm{dS} \mathrm{m}^{-1}$ ) maruz bırakılan dört şeker pancarı çeşidinde (Orthega, Valentina, FD Shoot ve Mohican) morfolojik ve fizyolojik özellikler incelenmiştir. Çimlenme testinde; çimlenme yüzdesi, ortalama çimlenme süresi, fide uzunluğu ve fide yaş ağırlığı, çıkış testinde; çıkış yüzdesi, ortalama çıkış süresi, kök uzunluğu, sürgün uzunluğu, bitki yaş ağırlığı, bağıl su içeriği, bağıl klorofil içeriği ve elektrolit sızıntısı ölçülmüştür. Sonuçlar, FD Shoot çeşidinde en yüksek çimlenmenin kontrol, en düşük çimlenmenin ise $15 \mathrm{dS} \mathrm{m}^{-1}$ seviyesinde kaydedildiğini göstermiştir. Çıkış testindeki tüm $\mathrm{NaCl}$ seviyelerinde en yüksek çıkış yüzdesi Orthega ve Mohican çeşitlerinde tespit edilmiştir. Artan $\mathrm{NaCl}$ seviyeleri ile şeker pancarı çeşitlerinde ortalama çıkış süresi gecikmiş ve sürgün uzunluğu, kök uzunluğu ve bağıl su içeriği azalmıştır. Bağıl klorofil içeriği ve elektrolit sızıntısı, kontrol ve $10 \mathrm{dS} \mathrm{m} \mathrm{m}^{-1}$ seviyelerinde sırasıyla 32,7 SPAD ve \%21,6; 38,5 SPAD ve \%35,6 olarak belirlenmiştir. Genel olarak, şeker pancarı çeşitleri arasında önemli farklılıklar bulunmuş ve incelenen özellikler açısından çeșitler $5 \mathrm{dS} \mathrm{m}^{-1} \mathrm{e}$ kadar olan tuzluluğa tolerans göstermişlerdir. Bağıl klorofil içeriği ve elektrolit sızıntısının, tuzluluğa toleranslı veya hassas şeker pancarı çeşitlerinin seçiminde umut verici bir ipucu olarak kullanılması gerektiği sonucuna varılmıştır.

\section{Introduction}

Soil salinity occurs naturally in arid and semiarid regions where evapotranspiration is greater than precipitation. In irrigated areas, excessive amounts of irrigation water and low quality irrigation water use cause the accumulation of salts in soil. Salt stress is one of the most significant abiotic stresses inhibiting plant growth (Hampson \& Simpson 1990, Neumann 1995) and resulting in a wide number of irregularities in morphological, physiological and biochemical processes from germination to harvest (Willenborg et al. 2004). 
However, seed germination and early seedling growth are the most sensitive phases in many crops to salt stress (Almansouri et al. 2001).

Sugar used for human consumption is obtained from sugar beet and sugar cane in the world, while it is produced only from sugar beet in Turkey. Sugar beet is classified as a salt tolerant crop (Katerji et al. 2000, Yang et al. 2012), although it is sensitive to increased salinity at germination and early seedling stages (Ghoulam \& Fares 2001). Routinely, germination and seedling development properties have been tested for salinity tolerance because they are the most sensitive stage in plant life cycle. Jamil \& Rha (2004) recorded a significant reduction in germination percentage and a delay in required time to germination, but Jafarzadeh \& Aliasgharzad (2007) indicated that there was genotypic variation for germination rate among sugar beet cultivars. Also, Higazy et al. (1995) and Mekki \& El-Gazzar (1999) reported that salinity stress caused a depressed seedling growth, especially in the seedling fresh and dry weights of sugar beet. Moreover, relative water content, electrolyte leakage and chlorophyll content were recently used for indicators of salinity in barley (Ashraf 2004), in wheat (Farooq \& Azam 2006, Jamali et al. 2015). In sugar beet, decreased relative water content and chlorophyll content in leaves (Khorshid et al. 2018) and increased electrolyte leakage under $\mathrm{NaCl}$ were reported by Wang et al. (2017) but Skorupa et al. (2019) determined no changes in chlorophyll content. Due to the controversial reports and lack of sufficient researches, physiological traits needs to be confirmed by comparing salt stress sensitive and tolerant cultivars in sugar beet. This study aimed to investigate for any potential characteristics to be used for salt-tolerant sugar beet cultivars considering germination, early seedling development traits, relative water content, chlorophyll content and electrolyte.

\section{Materials and Methods}

The study was carried out at the Department of Field Crops, Faculty of Agriculture, Eskişehir Osmangazi University, Turkey in 2019. Extensively preferred four sugar beet cultivars (Orthega, Valentina, FD Shoot, and Mohican) from three seed companies and $\mathrm{NaCl}$ (Merck) were used in the experiments. Salinity levels were arranged as decreasing in germination and emergence percentage and they were constituted as low $\left(5 \mathrm{dS} \mathrm{m}^{-1}\right)$, medium $\left(10 \mathrm{dS} \mathrm{m}^{-1}\right)$, and high $\left(15 \mathrm{dS} \mathrm{m}^{-1}\right)$ salinity with WTW 3.15 conductivity meter (Germany). Distilled water $\left(0 \mathrm{dS} \mathrm{m}^{-1}\right)$ was used as control.

In the germination experiment, it was aimed to simulate the soil salinity because the seeds were directly placed into salt-contaminated soils. Two hundred seeds as four replicates $(4 \times 50)$ were employed for each cultivar and salinity level. The fifty seeds were counted and inserted into three layers of sterile filter paper with $21 \mathrm{~mL}$ of respective salt solutions. As soon as the papers were gently rolled, they were put into sealed plastic bags to prevent water loss. These bags were transferred to the incubator at a constant temperature of $25 \pm 1^{\circ} \mathrm{C}$ in the dark.
Germinated seeds with a $2 \mathrm{~mm}$ radicle were counted every day for 14 days period. The mean germination time (MGT) was calculated as described in Anonymous (2003). Seedling length and seedling fresh weight were measured at the end of the experiment.

The emergence experiment was designed for simulation of irrigation water salinity under laboratory conditions. It was conducted in peat-filled plastic containers with 100 seeds $(4 \times 25)$ and the seeds of each sugar beet cultivar were sown individually at a depth of $2 \mathrm{~cm}$. The plastic containers were placed in the growth chamber after they were irrigated with respective salt solutions. Emergence percentage, mean emergence time (MET), fresh plant weight, root length, shoot length, relative chlorophyll content $(\mathrm{Chl})$, relative water content (RWC) and electrolyte leakage were measured at $28^{\text {th }}$ day after sowing. Leaf relative Chl was measured at the third leaf from the top of plants by using Konica Minolta SPAD-502 meter. Leaf RWC was assessed on fully enlarged leaves of five plants per replicate. Five leaves were pulled out from each replication and immediately weighed fresh weight $(\mathrm{FW})$. They were immersed in distilled water in a falcon tube for $24 \mathrm{~h}$ to regain turgidity, and then turgor weight (TW) was weighted. The samples were dried at $70^{\circ} \mathrm{C}$ for $48 \mathrm{~h}$ in order to determine the dry weight (DW). RWC of the leaves was calculated following the formula (Ghoulam et al. 2002) (Eq. 1).

$$
R W C(\%)=[(F W-D W) /(T W-D W)] \times 100(E q .1)
$$

After the plants were harvested, the electrical conductivity (EC) values of the growing medium were determined. The saturated paste extract was prepared with a 1:10 medium to water ratio and the EC was measured with the EC meter at $25^{\circ} \mathrm{C}$ after $24 \mathrm{~h}$ with three replicates for each treatment.

Electrolyte leakage was analyzed by using young leaf discs of five plants from each treatment. Leaf samples were washed with deionized water to eliminate electrolytes on the surface of the leaves. Five leaf disks with $10 \mathrm{~mm}$ diameter were excised, weighed and placed into glass tubes filled with $20 \mathrm{~mL}$ of deionized water. After the incubation period for $24 \mathrm{~h}$ at $25^{\circ} \mathrm{C}$, the solution's electrical conductivity $\left(\mathrm{L}_{\mathrm{t}}\right)$ was directly read by the EC meter. They were then autoclaved for $20 \mathrm{~min}$ at $121^{\circ} \mathrm{C}$, and the electrical conductivity $\left(\mathrm{L}_{\mathrm{o}}\right)$ was recorded again at $25^{\circ} \mathrm{C}$ after equilibration (Yadav et al. 2012). The electrolyte leakage was calculated by the formula of Ghoulam et al. (2002) as follows (Eq. 2).

$$
\text { Electrolyte leakage }(\%)=\left(L_{t} / L_{o}\right) \times 100(E q .2)
$$

The experimental design was a 2-factor factorial, arranged in a completely randomized design with 4 replications. Analysis of variance was performed by the MSTAT-C software program (Michigan State University, v 2.10). Significant differences among the mean values were compared by Duncan's Multiple Range test $(\mathrm{p}<0.05)$. 


\section{Results}

Germination performance and seedling development of sugar beet cultivars in the germination experiment were negatively influenced by increasing $\mathrm{NaCl}$ levels (Table 1). Mean values of sugar beet cultivars showed that differences were detected for the investigated traits. Among the cultivars, Mohican gave the highest germination percentage and seedling length, while Ortega produced the heavier fresh weight. At the highest $\mathrm{NaCl}$ level of $15 \mathrm{dS} \mathrm{m}^{-1}$, Mohican had the maximum germination percentage, while a dramatic decrease in germination rate of FD Shoot was observed. Considering mean values of $\mathrm{NaCl}$ levels, increased $\mathrm{NaCl}$ caused a significant reduction in germination, seedling length and seedling fresh weight, but MGT was retarded. Mean values obtained from four cultivars showed higher germination, seedling length and seedling fresh weight; however, the interaction between cultivar and salinity was significant.

Interaction of cultivar $\times \mathrm{NaCl}$ levels showed that germination percentage of cultivar FD Shoot linearly declined due to an increase in $\mathrm{NaCl}$ (Fig. 1a). Under salt stresses, Orthega and Valentina germinated higher than the other cultivars, while the germination rate of Mohican did not change. MGT was clearly delayed by increasing salinity; the most rapid germination was obtained from Valentina (Fig. 1b). The response of seedling length of sugar beet cultivars to salinity levels was different and FD Shoot had the shortest seedling at $15 \mathrm{dS} \mathrm{m}^{-1}$ (Fig. 1c).

Table 1. Analysis of variance and mean values of germination and early seedling growth parameters of sugar beet cultivars under salinity conditions in the germination experiment. The means \pm SD of four replicates were given. Different letters denote statistically significant differences by Duncan's Multiple Range test $(\mathrm{p}<0.05)$ among all treatments respectively.

\begin{tabular}{|c|c|c|c|c|}
\hline Factors & $\begin{array}{c}\text { Germination } \\
\text { percentage } \\
(\%)\end{array}$ & $\begin{array}{c}\text { Mean } \\
\text { germination } \\
\text { time } \\
\text { (day) }\end{array}$ & $\begin{array}{l}\text { Seedling } \\
\text { length } \\
\text { (cm) }\end{array}$ & $\begin{array}{c}\text { Seedling } \\
\text { fresh weight } \\
\left(\mathrm{mg} \mathrm{plant}^{-1}\right)\end{array}$ \\
\hline \multicolumn{5}{|l|}{ Cultivars } \\
\hline Orthega & $62.7^{b} \pm 9.50$ & $4.61^{b} \pm 1.27$ & $7.06^{\mathrm{b}} \pm 0.46$ & $44.4^{\mathrm{a}} \pm 5.39$ \\
\hline Valentina & $61.1^{\mathrm{b}} \pm 6.37$ & $3.89^{\mathrm{c}} \pm 0.75$ & $7.49^{\mathrm{b}} \pm 0.94$ & $33.2^{c} \pm 5.73$ \\
\hline FD Shoot & $49.3^{c} \pm 28.5$ & $5.50^{\mathrm{a}} \pm 1.90$ & $6.95^{\mathrm{b}} \pm 2.29$ & $42.5^{\mathrm{ab}} \pm 12.9$ \\
\hline Mohican & $66.3^{\mathrm{a}} \pm 3.04$ & $4.07^{c} \pm 1.06$ & $8.62^{\mathrm{a}} \pm 1.14$ & $40.8^{\mathrm{b}} \pm 5.84$ \\
\hline \multicolumn{5}{|c|}{$\mathrm{NaCl}\left(\mathrm{dS} \mathrm{m} \mathbf{m}^{-1}\right)$} \\
\hline Control & $71.8^{\mathrm{a}} \pm 6.77$ & $3.30^{\mathrm{d}} \pm 0.35$ & $7.24^{\mathrm{b}} \pm 0.57$ & $38.6^{\mathrm{c}} \pm 6.17$ \\
\hline 5 & $63.3^{b} \pm 3.42$ & $3.71^{\mathrm{c}} \pm 0.40$ & $8.97^{\mathrm{a}} \pm 1.09$ & $49.1^{\mathrm{a}} \pm 6.90$ \\
\hline 10 & $57.1^{c} \pm 12.1$ & $5.08^{\mathrm{b}} \pm 1.02$ & $7.61^{\mathrm{b}} \pm 0.60$ & $41.4^{\mathrm{b}} \pm 5.04$ \\
\hline 15 & $47.2^{\mathrm{d}} \pm 23.1$ & $5.97^{\mathrm{a}} \pm 1.26$ & $6.30^{c} \pm 1.80$ & $31.8^{\mathrm{d}} \pm 6.62$ \\
\hline \multicolumn{5}{|c|}{ Analysis of Variance } \\
\hline D Cultivars (A) & 0.000 & 0.000 & 0.000 & 0.000 \\
\hline $\mathrm{D} \mathrm{NaCl}(\mathrm{B})$ & 0.000 & 0.000 & 0.000 & 0.000 \\
\hline $\mathrm{D}_{\mathrm{A} \times \mathrm{B}}$ & 0.000 & 0.000 & 0.000 & 0.000 \\
\hline
\end{tabular}

(a) Orthega $\square$ Valentina $\square$ FD Shoot $\square$ Mohican

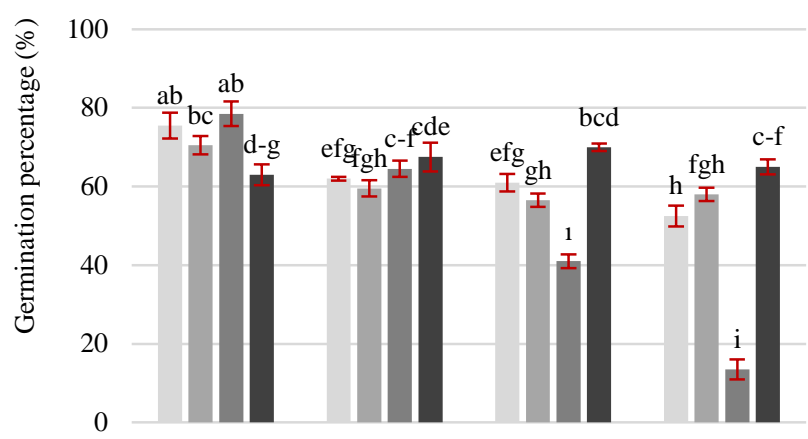

(b) 10

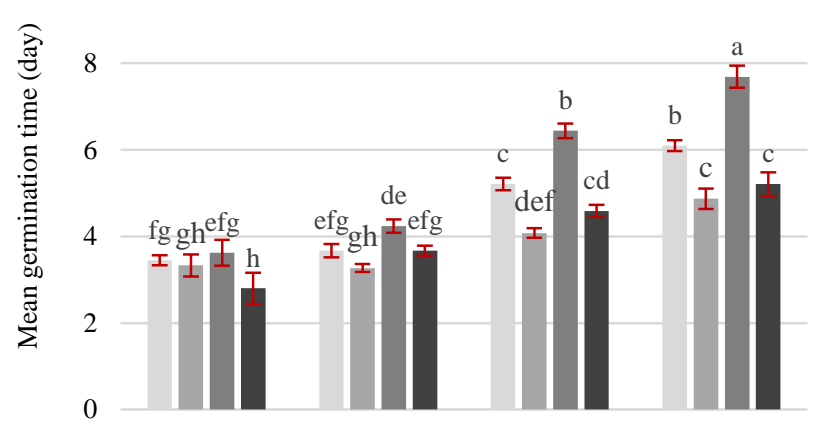

(c) 12
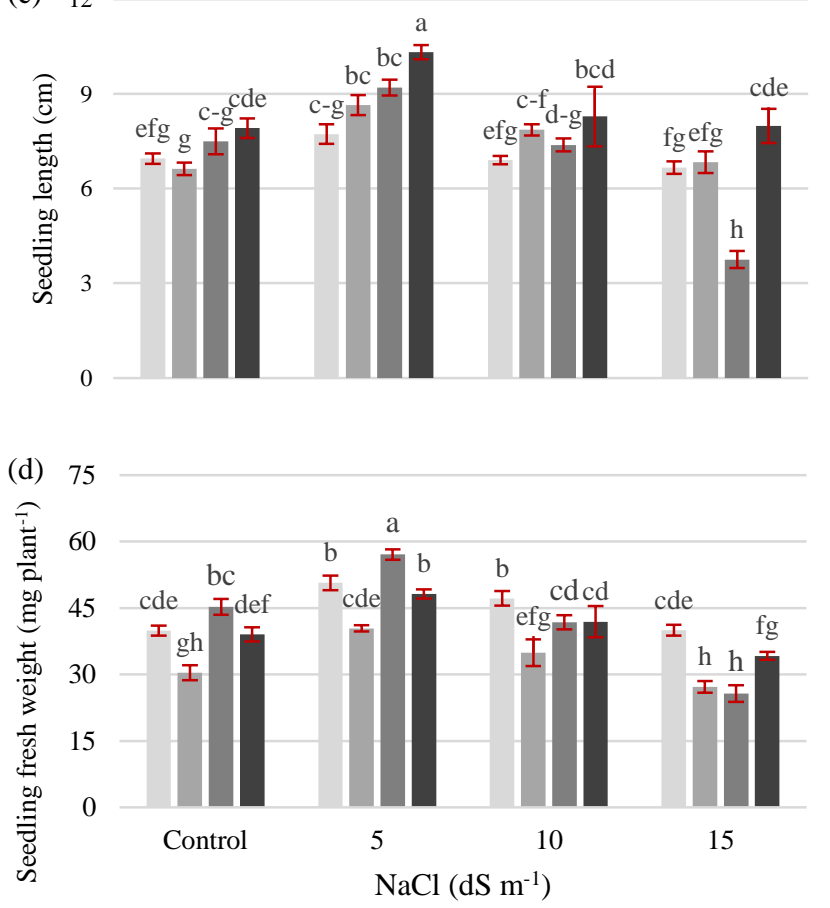

Fig. 1. Interaction of cultivar $x \mathrm{NaCl}$ level for a) germination percentage, b) mean germination time, c) seedling length, d) seedling fresh weight of sugar beet cultivars in the germination experiment. The means $\pm \mathrm{SD}$ of four replicates were given. Different letters denote statistically significant differences by Duncan's Multiple Range test $(\mathrm{p}<0.05)$ among all treatments respectively. 


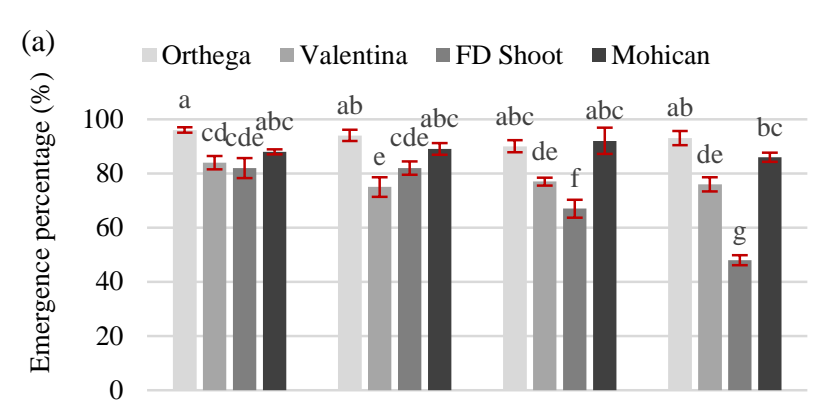

(1)
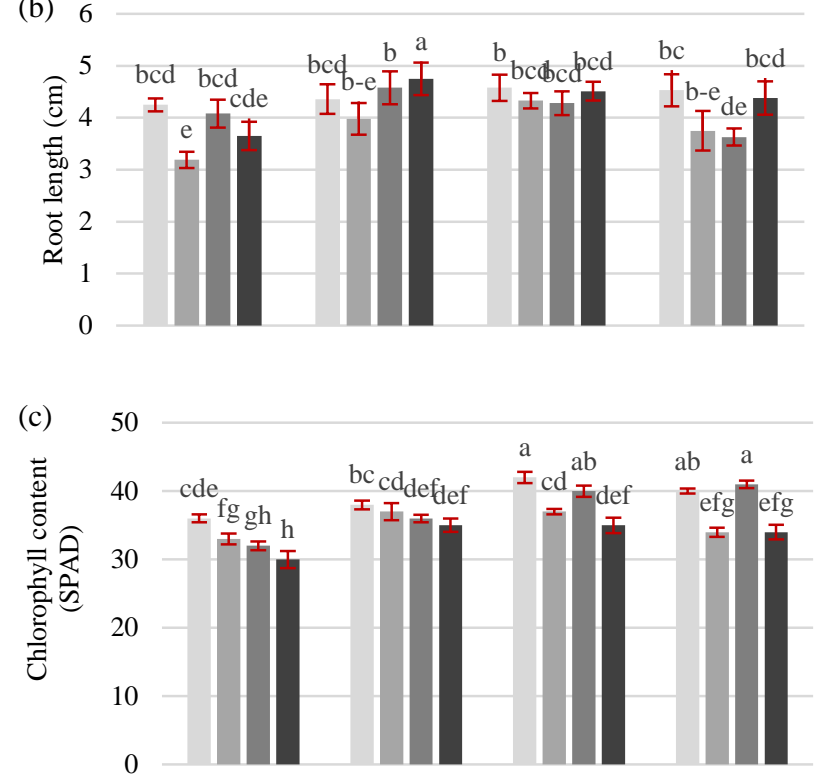

(d) 50

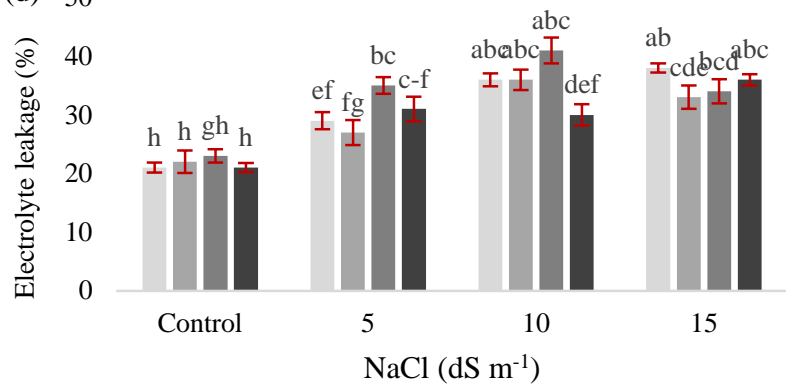

Fig. 2. Interaction of cultivar $x \mathrm{NaCl}$ level for a) emergence percentage, b) root length, c) relative chlorophyll content, d) electrolyte leakage of sugar beet in the pod experiment. The means \pm SD of four replicates were given. Different letters denote statistically significant differences by Duncan's Multiple Range test $(\mathrm{p}<0.05)$ among all treatments respectively.

Similar results were obtained from the other sugar beet cultivars and the minimum level of $\mathrm{NaCl}$ promoted the seedling growth. Seedling fresh weight evidently increased at $\mathrm{NaCl}$ levels of $5 \mathrm{dS} \mathrm{m}^{-1}$; that is why low doses of salts act as plant nutrition during short periods at early development stage. A remarkable reduction in SFW occurred at $15 \mathrm{dS} \mathrm{m}^{-}$ ${ }^{1}$ along with significant changes among cultivars. Seedling fresh weight of Orthega did not change from control to 15 $\mathrm{dS} \mathrm{m}{ }^{-1}$, but FD Shoot was clearly depressed (Fig. 1d).
In the pod experiments, main factors and interaction effects of the investigated characters of sugar beet cultivars subjected to different $\mathrm{NaCl}$ levels were given in Table 2. A two-way interaction was significant for emergence percentage, root length, relative chlorophyll content and electrolyte leakage, and the interactions were displayed in Fig. 2. Orthega had the highest emergence percentage of $92.8 \%$, while FD Shoot had the lowest emergence with $69.3 \%$. Increasing $\mathrm{NaCl}$ levels resulted in decreased emergence percentage from $87.0 \%$ in control to $75.5 \%$ at $15 \mathrm{dS} \mathrm{m} \mathrm{m}^{-1}$. FD Shoot was the most severely affected by $\mathrm{NaCl}$ and its emergence percentage was dramatically decreased at $10 \mathrm{dS} \mathrm{m}^{-1}$ and above (Fig 2a). MET was adversely affected by increasing $\mathrm{NaCl}$ and the shortest time to emergence was recorded in Orthega. Among the cultivars, Mohican had the longest root length with $4.57 \mathrm{~cm}$, followed by Orthega with $4.43 \mathrm{~cm}$. Under all $\mathrm{NaCl}$ levels, sugar beet seedlings produced longer root length than control. Shorter root length at $15 \mathrm{dS} \mathrm{m}^{-1}$ than control was attained in FD Shoot and the other cultivars produced the longest root length (Fig 2b).

Shoot length varied between $2.73 \mathrm{~cm}$ and $3.27 \mathrm{~cm}$, Orthega and Valentina had the higher values compared to FD Shoot and Mohican. Shoot length was severely decreased when $\mathrm{NaCl}$ levels increased. On the other hand, $\mathrm{NaCl}$ dose of $5 \mathrm{dS} \mathrm{m}^{-1}$ showed a promoter effect on fresh plant weight, significant reductions were observed at 10 and $15 \mathrm{dS} \mathrm{m}^{-1}$.

Physiological parameters were apparently changed by sugar beet cultivars and $\mathrm{NaCl}$ levels. Orthega had the highest $\mathrm{Chl}$, while the maximum RWC and electrolyte leakage was obtained from FD Shoot. Increasing salinity levels led to an increase in $\mathrm{Chl}$ and electrolyte leakage, and the highest values were detected at $10 \mathrm{dS} \mathrm{m}^{-1}$ and dropped at $15 \mathrm{dS} \mathrm{m} \mathrm{m}^{-1}$. An apparent increase in Chl content of Orthega and FD Shoot was observed under $\mathrm{NaCl}$, but this increase was at minimal level in Mohican and Valentina (Fig. 2c). Considerable variations were found for RWC and electrolyte leakage. RWC reduced by increasing salinity and decreased from $76.7 \%$ to 64.9\%. FD Shoot exhibited the highest RWC with $72.3 \%$. Salinity induced significant decrease in RWC at higher salinity levels compared to the control. Salt treatment caused a highly significant decrease in RWC of the investigated cultivars. RWC decreased with the increase of salt concentration and less effect was recorded in FD Shoot. Electrolyte leakage reached the maximum level at $15 \mathrm{dS} \mathrm{m}^{-1}$ except for Valentina and FD Shoot at $10 \mathrm{dS} \mathrm{m}^{-1}$, whose electrolyte leakage values declined at $15 \mathrm{dS} \mathrm{m}^{-1}$.

Comparison of electrical conductivity values of the growing medium at the end of the pod experiment was illustrated in Fig. 3. At control and $5 \mathrm{dS} \mathrm{m}^{-1}$, no significant changes in EC values of growing medium were observed among sugar beet cultivars. The medium of Orthega and FD Shoot possessed lower EC values at $10 \mathrm{dS} \mathrm{m}^{-1}$, while they were higher at $15 \mathrm{dS} \mathrm{m}^{-1}$ than that of Mohican and Valentina. 
Table 2. Analysis of variance and main effects of sugar beet cultivars and $\mathrm{NaCl}$ levels for emergence percentage (EP), mean emergence time (MET), root length, shoot length, fresh plant weight (FPW), relative chlorophyll content (Chl), relative water content (RWC) and electrolyte leakage (EL) of 28-day old sugar beet plants in the pod experiment. The means \pm SD of four replicates were given. Different letters denote statistically significant differences by Duncan's Multiple Range test $(p<0.05)$ among all treatments respectively.

\begin{tabular}{|c|c|c|c|c|c|c|c|c|}
\hline Factors & $\begin{array}{l}\text { EP } \\
(\%)\end{array}$ & $\begin{array}{l}\text { MET } \\
\text { (day) }\end{array}$ & $\begin{array}{l}\text { Root length } \\
\text { (cm) }\end{array}$ & $\begin{array}{c}\text { Shoot length } \\
(\mathrm{cm})\end{array}$ & $\begin{array}{c}\text { FPW } \\
\left(\text { mg plant }^{-1}\right)\end{array}$ & $\begin{array}{c}\text { Chl } \\
\text { (SPAD) }\end{array}$ & $\begin{array}{c}\text { RWC } \\
(\%)\end{array}$ & $\begin{array}{l}\text { EL } \\
(\%)\end{array}$ \\
\hline \multicolumn{9}{|l|}{ Cultivars } \\
\hline Orthega & $92.8^{\mathrm{a}} \pm 2.56$ & $6.02^{\mathrm{c}} \pm 0.72$ & $4.43^{\mathrm{a}} \pm 0.15$ & $3.27^{\mathrm{a}} \pm 0.72$ & $1036^{\mathrm{a}} \pm 165$ & $39.0^{\mathrm{a}} \pm 2.62$ & $69.4^{\mathrm{ab}} \pm 4.51$ & $30.9^{\mathrm{b}} \dagger \pm 7.98$ \\
\hline Valentina & $77.6^{c} \pm 4.01$ & $6.29^{c} \pm 0.79$ & $3.81^{\mathrm{c}} \pm 0.48$ & $3.16^{\mathrm{a}} \pm 0.84$ & $820^{b} \pm 221$ & $35.1^{\mathrm{c}} \pm 2.09$ & $66.2^{\mathrm{b}} \pm 5.28$ & $29.2^{\mathrm{b}} \pm 6.15$ \\
\hline FD Shoot & $69.3^{\mathrm{d}} \pm 15.9$ & $7.04^{\mathrm{a}} \pm 1.04$ & $4.14^{\mathrm{bc}} \pm 0.40$ & $2.77^{b} \pm 0.65$ & $1131^{a} \pm 336$ & $37.0^{\mathrm{b}} \pm 4.27$ & $72.3^{a} \pm 5.99$ & $33.2^{\mathrm{a}} \pm 7.40$ \\
\hline Mohican & $88.5^{b} \pm 2.74$ & $6.65^{b} \pm 0.76$ & $4.57^{\mathrm{a}} \pm 0.87$ & $2.73^{b} \pm 0.45$ & $1032^{\mathrm{a}} \pm 229$ & $33.5^{\mathrm{d}} \pm 2.13$ & $67.7^{\mathrm{ab}} \pm 6.90$ & $29.6^{b} \pm 6.15$ \\
\hline \multicolumn{9}{|c|}{$\mathrm{NaCl}\left(\mathrm{dS} \mathrm{m}^{-1}\right)$} \\
\hline Control & $87.0^{\mathrm{a}} \pm 6.19$ & $5.81^{\mathrm{c}} \pm 0.33$ & $3.79^{\mathrm{c}} \pm 0.47$ & $3.77^{\mathrm{a}} \pm 0.42$ & $1125^{b} \pm 178$ & $32.7^{\mathrm{c}} \pm 2.26$ & $76.7^{a} \pm 3.32$ & $21.6^{\mathrm{c}} \pm 1.01$ \\
\hline 5 & $84.7^{\mathrm{ab}} \pm 8.55$ & $5.97^{c} \pm 0.43$ & $4.67^{\mathrm{a}} \pm 0.76$ & $3.06^{b} \pm 0.50$ & $1238^{a} \pm 156$ & $36.3^{\mathrm{b}} \pm 1.53$ & $67.6^{\mathrm{b}} \pm 2.11$ & $30.6^{b} \pm 3.54$ \\
\hline 10 & $81.1^{\mathrm{b}} \pm 11.8$ & $6.61^{b} \pm 0.54$ & $4.42^{a b} \pm 0.14$ & $2.86^{\mathrm{b}} \pm 0.22$ & $960^{c} \pm 147$ & $38.5^{\mathrm{a}} \pm 3.00$ & $66.4^{b} \pm 4.57$ & $35.6^{\mathrm{a}} \pm 4.30$ \\
\hline 15 & $75.5^{c} \pm 19.5$ & $7.60^{\mathrm{a}} \pm 0.61$ & $4.07^{\mathrm{bc}} \pm 0.44$ & $2.23^{c} \pm 0.21$ & $696^{\mathrm{d}} \pm 106$ & $37.2^{b} \pm 3.99$ & $64.9^{b} \pm 2.96$ & $35.2^{\mathrm{a}} \pm 2.37$ \\
\hline \multicolumn{9}{|c|}{ Analysis of Variance } \\
\hline D Cultivars (A) & 0.000 & 0.000 & 0.001 & 0.001 & 0.000 & 0.000 & 0.050 & 0.004 \\
\hline $\mathrm{D} \mathrm{NaCl}(\mathrm{B})$ & 0.000 & 0.000 & 0.000 & 0.000 & 0.000 & 0.000 & 0.000 & 0.000 \\
\hline $\mathrm{D}_{\mathrm{A} \times \mathrm{B}}$ & 0.000 & 0.312 & 0.010 & 0.160 & 0.252 & 0.000 & 0.332 & 0.004 \\
\hline
\end{tabular}

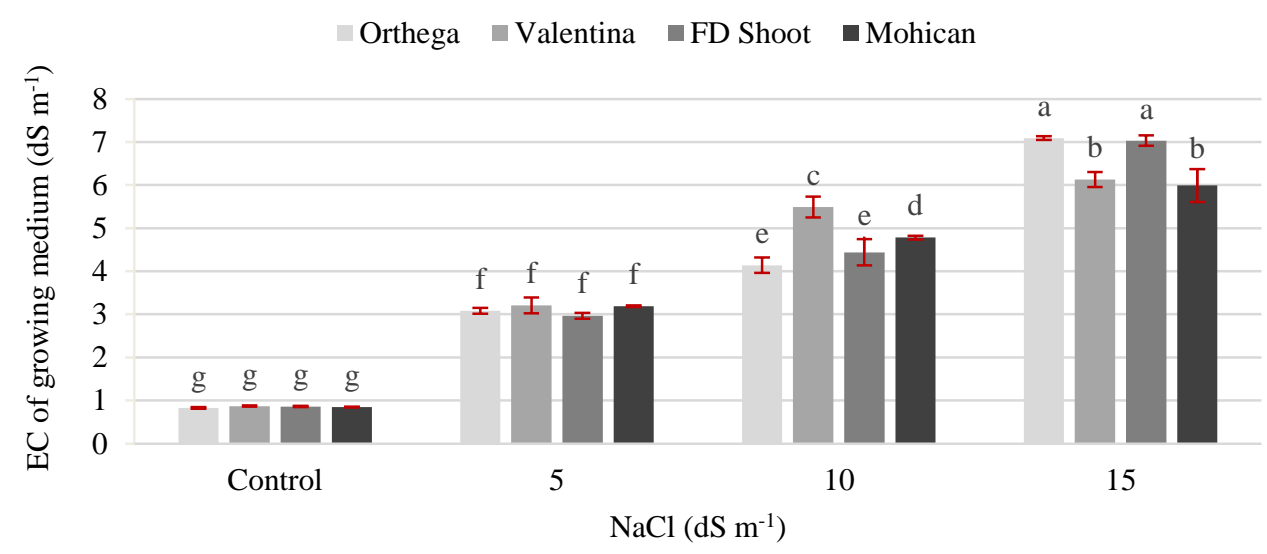

Fig. 3. Electrical conductivity values $(1: 10)$ of growing medium after the pod experiment according to NaCl levels and sugar beet cultivars. The means \pm SD of four replicates were given. Different letters denote statistically significant differences by Duncan's Multiple Range test $(\mathrm{p}<0.05)$ among all treatments respectively.

\section{Discussion}

The primary effect of salinity stress in plants is restriction of water uptake, ion imbalance and toxicity. Sugar beet is often exposed to salinity by means of irrigation water or naturally saline soils in arid and semiarid regions in Turkey. For this reason, it is necessary to improve salt tolerant sugar beet cultivars or to select the tolerant cultivars. Our results showed that germination performance was reduced and delayed due to increasing $\mathrm{NaCl}$ levels with significant variation among sugar beet cultivars. The inhibitory effect of salinity on germination was not determined in Mohican, but MGT was delayed. The results are in agreement with Mostafavi (2012), Khayamim et al. (2014) and Pinheiro et al. (2018) who observed that sugar beet cultivars were adversely affected by high salt doses and their MGT was prolonged. Kandil et al. (2014) found that increasing salinity levels significantly decreased germination percentage, while the shortest MGT was recorded in control. They confirmed that there was genotypic variation among sugar beet cultivars in terms of germination rate and MGT under salinity. Early seedling development was not inhibited up to $\mathrm{NaCl}$ level of $15 \mathrm{dS} \mathrm{m}^{-1}$, while sugar beet cultivars showed different responses to salinity. FD Shoot was the most adversely influenced with respect to seedling length and seedling fresh weight. On the other hand, Mohican and Orthega exhibited better performance as $\mathrm{NaCl}$ levels increased. Our results confirmed the findings of Mostafavi (2012), Jamil \& Rha (2004) and Khorshid et al. (2018). They determined a significant reduction in root, shoot length and seedling fresh weight due to increasing salinity. Similar results were obtained from several plants such as soybean (Amirjani 2010) and nine vegetables (Shannon et al. 2000). Decreased emergence percentage and retarded MET were determined under $\mathrm{NaCl}$ stresses. Mahmoud \& Hill (1981) indicated that higher salt levels resulted in reduced and delayed emergence compared to control. Generally, emergence performance was confirmed by germination percentage and MGT. However, germination percentage was observed lower than the emergence percentage in our study. That is why sugar beet seeds have germination inhibitors (Salimi \& Boelt 2019) and pleated papers are advised for 
germination test. On the other hand, flat papers were employed in this study in order to prevent the leakage of salt ions from germination medium and lower germination rate were achieved than emergence rate.

Root length is considered as an important clue to the response of plants to salt stress, so that they are in contact with soil and absorb water and nutrients from the soil (Kaya et al. 2003). Taghizadegan et al. (2019) reported that the root length increased by salinity compared to control. Root length showed differences among sugar beet cultivars. Orthega and Mohican were the least affected cultivars by $\mathrm{NaCl}$. Jafarzadeh \& Aliasgharzad (2007) recorded a decrease in root length at $16 \mathrm{dS} \mathrm{m}^{-1}$ and no considerable change was observed up to $14 \mathrm{dS} \mathrm{m}^{-1}$. Shoot length was the most sensitive character and it was gradually decreased with increasing $\mathrm{NaCl}$. Orthega and Valentina produced longer shoot than the others. Jamil \& Rha (2004) reported that salinity significantly reduced shoot length of sugar beet, and shoot length was more sensitive than root length (AboKassem 2007). Depending on the decrease in root and shoot length, FPW was reduced by $\mathrm{NaCl}$ levels. The findings of Mostafavi (2012), Jamil et al. (2012) and Khayamim et al. (2014) confirmed these results. Chl under increasing salinity was changed by sugar beet cultivars. FD Shoot showed linear increases up to $15 \mathrm{dS} \mathrm{m}^{-1}$, while Valentina gradually increased at $10 \mathrm{dS} \mathrm{m}^{-1}$ and decreased at $15 \mathrm{dS} \mathrm{m}^{-1}$. Contrarily, Wang et al. (2017) stated a clear reduction in $\mathrm{Chl}$ in sugar beet as $\mathrm{NaCl}$ increased. Skorupa et al. (2019) determined that no change was recorded in Chl under saline conditions. The difference in $\mathrm{Chl}$ could be resulted from genotypic variation or their tolerance levels and duration of exposure to salinity. RWC diminished when the salinity level increased. Mensah et al. (2006) found that the RWC of the pea cultivars under salt stress decreased. Similarly, Ghoulam et al. (2002), Wang et al. (2017), Skorupa et al. (2019), Taghizadegan et al. (2019), Tahjib-Ul-Arif et al. (2019) and Wang et al. (2019) reported that increasing salinity resulted in a decrease in RWC in sugar beet. The decline in RWC stated a loss of turgor leading to limited available water for the cell extension process (Ghoulam et al. 2002); consequently, inhibition of growth in FD Shoot might be linked to a decline in RWC caused by salinity stress. Our results showed that salinity induced electrolyte leakage from the leaves of all sugar beet cultivars. This finding was supported by Ghoulam et al. (2002), Dadkhah (2011) and Romano et al. (2019), who reported that the electrolyte leakage was raised with higher salinities. Excessive accumulation of $\mathrm{Na}^{+}$and $\mathrm{Cl}^{-}$ions in plant tissue causes ion

\section{References}

1. Abo-Kassem, E.ED.M. 2007. Effects of Salinity: Calcium interaction on growth and nucleic acid metabolism in five spices of Chenopodiaceae. Turkish Journal of Botany, 31: 125-134.

2. Almansouri, M., Kinet, J.M. \& Lutts, S. 2001. Effect of salt and osmotic stresses on germination in durum wheat (Triticum durum Desf.). Plant Soil, 231: 243-254. imbalance and deformation, even resulted in killing the cells, which led to improve the ionic leakage from leaves; therefore, higher electrolyte leakage was observed in lower salt tolerant plants. It is used to measure the stability of the cellular membranes against any stress factors. In previous studies, enhanced salinity levels caused by cell membrane injury and electrolyte leakage were supported by Dadkhah (2011) in sugar beet and Dkhil \& Denden (2012) in okra.

\section{Conclusion}

Sugar beet is considered to be a salinity tolerant plant; however, its tolerance level depends on two main factors, the cultivar and the plant development stage. The seeds of sugar beet are firstly exposed to salinity when they are sown into soils contaminated by salinity or irrigated with water with low quality for emergence. Improvement of salt tolerant cultivars is necessary and/or tolerant cultivars should be selected for successful production in saline soils. In this study, four sugar beet cultivars were imposed to germinate under saline conditions and allowed to grow seedlings. Among the investigated cultivars, Mohican and Orthega were found to be more salt tolerant than the others and the most sensitive cultivar was FD Shoot. Similar trends between germination results and the findings of the emergence experiment were identified. The results of relative chlorophyll content and electrolyte leakage were prominently changed according to salttolerant and sensitive cultivars, and consequently, they should be considered for suitable selection criteria for salinity in sugar beet. However, further research should be conducted with more sugar beet cultivars in order to explain precisely the relationship between the germination and physiological properties, and to determine their responses to salinity at successive development stages under field conditions.

Ethics Committee Approval: Since the article does not contain any studies with human or animal subject, its approval to the ethics committee was not required.

Author Contributions: Concept: A.A., M.D.K., Desing: A.A., M.D.K., Execution: A.A., E.G.K., Material supplying: A.A., M.D.K., Data acquisition: M.D.K., N.E., E.G.K., Data analysis/interpretation: M.D.K., N.E., E.G.K., Writing: M.D.K., N.E., E.G.K., Critical review: M.D.K.

Conflict of Interest: The authors have no conflicts of interest to declare.

Funding: The authors declared that this study has received no financial support.

3. Amirjani, M.R. 2010. Effect of salinity stress on growth, mineral composition, proline content, antioxidant enzymes of soybean. American Journal of Plant Physiology, 5(6): 350-360.

4. Anonymous, 2003. International Rules for Seed Testing. The International Seed Testing Association (ISTA), Edition 2003/1, Bassersdorf, CH-Switzerland. 
5. Ashraf, M. 2004. Some important physiological selection criteria for salt tolerance in plants. Flora-Morphology, Distribution, Functional Ecology of Plants, 199(5): 361376.

6. Dadkhah, A. 2011. Effect of salinity on growth and leaf photosynthesis of two sugar beet (Beta vulgaris L.) cultivars. Journal of Agricultural Science and Technology, 13(7): 1001-1012.

7. Dkhil, B.B. \& Denden, M. 2012. Effect of salt stress on growth, anthocyanins, membrane permeability and chlorophyll fluorescence of okra (Abelmoschus esculentus L.) seedlings. American Journal of Plant Physiology, 7(4): 174-183.

8. Farooq, S. \& Azam, F. 2006. The use of cell membrane stability (CMS) technique to screen for salt tolerant wheat varieties. Journal of Plant Physiology, 163: 629-637.

9. Ghoulam, C. \& Fares, K. 2001. Effect of salinity on seed germination and early seedling growth of sugar beet (Beta vulgaris L.). Seed Science and Technology, 29: 357-364.

10. Ghoulam, C., Foursy, A. \& Fares, K. 2002. Effects of salt stress on growth, inorganic ions and proline accumulation in relation to osmotic adjustment in five sugar beet cultivars. Environmental and Experimental Botany, 47(1): 39-50.

11. Hampson C.R. \& Simpson, G.M. 1990. Effects of temperature, salt and osmotic pressure on early growth of wheat (Triticum aestivum L.). 1. Germination. Canadian Journal of Botany, 68: 524-528.

12. Higazy, M.A., Shehata, M.M. \& Allam, A.I. 1995. Free proline relation to salinity tolerance of three sugar beet varieties. Egyptian Journal of Agricultural Research, 13(1): 175-190.

13. Jafarzadeh, A. \& Aliasgharzad, N. 2007. Salinity and salt composition effects on seed germination and root length of four sugar beet cultivars. Biologia, 62(5): 562-564.

14. Jamali, S.S., Borzouei, A., Aghamirzaei, M., Khosronejad, H.R. \& Fathi, M. 2015. Cell membrane stability and biochemical response of seven wheat cultivars under salinity stress. Brazilian Journal of Botany, 38(1): 63-69.

15. Jamil, M. \& Rha, E.S. 2004. The effect of salinity $(\mathrm{NaCl})$ on the germination and seedling of sugar beet (Beta vulgaris L.) and cabbage (Brassica oleracea L.). Plant Resources, 7(3): 226-232.

16. Jamil, M., Ashraf, M., Rehman, S., Ahmad, M. \& Rha, E.S. 2012. Salinity induced changes in cell membrane stability, protein and RNA contents. African Journal of Biotechnology, 11(24): 6476-6483.

17. Kandil, A.A., Sharief, A.E., Abido, W.A.E. \& Awed, A.M. 2014. Effect of gibberellic acid on germination behaviour of sugar beet cultivars under salt stress conditions of Egypt. Sugar Tech, 16(2): 211-221.

18. Katerji, N., Van Hoorn, J.W., Hamdy, A. \& Mastrorilli, M. 2000. Salt tolerance classification of crops according to soil salinity and to water stress day index. Agricultural Water Management, 43(1): 99-109.

19. Kaya, M.D., Ipek, A. \& Ozturk, A. 2003. Effects of different soil salinity levels on germination and seedling growth of safflower (Carthamus tinctorius L.). Turkish Journal of Agriculture and Forestry, 27(4): 221-227.

20. Khayamim, S., Tavkol Afshari, R., Sadeghian, S.Y., Poustini, K., Roozbeh, F. \& Abbasi, Z. 2014. Seed germination, plant establishment, and yield of sugar beet genotypes under salinity stress. Journal of Agricultural Science and Technology, 16(4): 779-790.

21. Khorshid, A.M., Moghadam, F.A., Bernousi, I., Khayamim, S. \& Rajabi, A. 2018. Comparison of some physiological responses to salinity and normal conditions in Sugar Beet. Indian Journal of Agricultural Research, 52(4): 362-367.

22. Mahmoud, E.A. \& Hill, M.J. 1981. Salt tolerance of sugar beet at various temperatures. New Zealand Journal of Agricultural Research, 24(1): 67-71.

23. Mekki, B.B. \& EL-Gazzar, M.M. 1999. Response of root yield and quality of sugar beet (Beta vulgaris L.) to irrigation with saline water and follar potassium fertilization. Annals of Agricultural Sciences, 44(1): 213225 .

24. Mensah, J.K., Akomeah, P.A., Ikhajiagbe, B. \& Ekpekurede, E.O. 2006. Effects of salinity on germination, growth and yield of five groundnut genotypes. African Journal of Biotechnology, 5(20): 1973-1979.

25. Mostafavi, K. 2012. Effect of salt stress on germination and early seedling growth stage of sugar beet cultivars. American-Eurasian Journal of Sustainable Agriculture, 6: 120-125.

26. Neumann, P.M. 1995. Inhabitation of content of germinating content root growth by salinity stress: Toxicity or an adaptive biophysical response. Pp. 299-304. In: Baluska, F., Ciamporova, M., Gasparikova, O. \& Barlow, P.W. (eds). Structure and Function of Roots. The Netherlands: Kluwer Academic Publishers, 354 pp.

27. Pinheiro, C., Ribeiro, I.C., Reisinger, V., Planchon, S., Veloso, M.M., Renaut, J., Eichacker, L. \& Ricardo, C.P. 2018. Salinity effect on germination, seedling growth and cotyledon membrane complexes of a Portuguese salt marsh wild beet ecotype. Theoretical and Experimental Plant Physiology, 30(2): 113-127.

28. Romano, A., Stevanato, P., Sorgona, A., Cacco, G. \& Abenavoli, M.R. 2019. Dynamic response of key germination traits to $\mathrm{NaCl}$ stress in sugar beet seeds. Sugar Tech, 21(4): 661-671.

29. Salimi, Z. \& Boelt, B. 2019. Optimization of germination inhibitors eliminating from sugar beet (Beta vulgaris L.) seeds of different maturity classes. Agronomy, 9(11): 763.

30. Shannon, M.C., Grieve, C.M., Lesch, S.M. \& Draper, J.H. 2000. Analysis of salt tolerance in nine leafy vegetables irrigated with saline drainage water. Journal of the American Society for Horticultural Science, 125(5): 658664.

31. Skorupa, M., Gołębiewski, M., Kurnik, K., Niedojadło, J., Kęsy, J., Klamkowski, K., Wójcik, K., Treder, W., Tretyn, A. \& Tyburski, J. 2019. Salt stress vs. salt shock-the case of sugar beet and its halophytic ancestor. BMC Plant Biology, 19(1): 1-18.

32. Taghizadegan, M., Toorchi, M., Vahed, M.M. \& Khayamim, S. 2019. Evaluation of sugar beet breeding 
populations based morpho-physiological characters under salinity stress. Pakistan Journal of Botany, 51(1): 11-17.

33. Tahjib-UI-Arif, M., Sohag, A.A.M., Afrin, S., Bashar, K.K., Afrin, T., Mahamud, A.G.M., Polash, M.A.S., Hossain, M.T., Sohel, M.A.T., Brestic, M. \& Murata, Y. 2019. Differential response of sugar beet to long-term mild to severe salinity in a soil-pot culture. Agriculture, 9(10): 223.

34. Wang, Y., Stevanato, P., Yu, L., Zhao, H., Sun, X., Sun, F., Li, J. \& Geng, G. 2017. The physiological and metabolic changes in sugar beet seedlings under different levels of salt stress. Journal of Plant Research, 130(6): 1079-1093.

35. Wang, Y., Stevanato, P., Lv, C., Li, R. \& Geng, G. 2019. Comparative physiological and proteomic analysis of two sugar beet genotypes with contrasting salt tolerance.
Journal of Agricultural and Food Chemistry, 67(21): 60566073.

36. Willenborg, C.J., Gulden, R.H., Johnson, E.N. \& Shirtliffe, S.J. 2004. Germination characteristics of polymer-coated canola (Brassica napus L.) seeds subjected to moisture stress at different temperatures. Agronomy Journal, 96: 786-791.

37. Yadav, N.S., Shukla, P.S., Jha, A., Agarwal, P.K. \& Jha, B. 2012. The SbSOS1 gene from the extreme halophyte Salicornia brachiata enhances $\mathrm{Na}+$ loading in xylem and confers salt tolerance in transgenic tobacco. BMC Plant Biology, 12: 188.

38. Yang, L., Ma, C., Wang, L., Chen, S. \& Li, H. 2012. Salt stress induced proteome and transcriptome changes in sugar beet monosomic addition line M14. Journal of Plant Physiology, 169: 839-850. 